\title{
POPIS REKONSTRUKCE DVOU STŘíBRNÝCH PÍŠŤAL Z URU
}

\author{
Marie Ondrǐičková*
}

\section{Description of the Reconstruction of the Silver Pipes from Ur}

\begin{abstract}
The paper focuses on the reconstruction of the silver flutes (pipes) discovered in Ur. These artifacts were found in a fragmentary state and this is the reason why we cannot offer perfect reconstruction. These artifacts are in the University of Pennsylvania Museum of Archaeology and Anthropology. The purpose of the paper is to provide probable evidence to support our hypothesis. The evidence can be found in several impression seals and depiction of a woman playing a pastoral whistle made of pearl shell. We will analyse material and written sources to describe a probable type of instrument corresponding to the aerophones of Ur. The second part of the paper includes a description of three experiments with mouthpieces. The silver pipes from Ur bring hypotetical tone scale, because we have no mouthpiece, which is the most important component. Experiment number 1 (the „arghul" instrument generated these tones: $a \sharp-g-f \sharp-e-d-c \sharp$. Experiment number 2 is an instrument with labium and its mode is not clear and exact. The pipe with three holes plays the tones: $c \sharp-a \sharp-g \sharp-f-d \sharp$ and the pipe with four holes produces: $a \sharp-g-f-d \sharp$. The pipes made of prepared metal sheets produces scales: $d \sharp-c \sharp-b-a \sharp$ (pipe with 3 holes) and $f-e-$ $d \sharp-d-c \sharp$. Sometimes the pitch tones are not clear, but all tones are part of the „embübu“ mode. The mode, as well as a pastoral whistle, is named in some written sources in Mesopotamian literary tradition.
\end{abstract}

Key words: silver pipes, Ur, iconography, reconstruction, aulos, arghul, artifacts.

DOI: https://doi.org/10.24132/actaff.2018.10.1.4

*Mgr. et Mgr. Marie Ondříčková, Ph.D., Katedra archeologie, Fakulta filozofická, Západočeská univerzita v Plzni, ondrickm@kar.zcu.cz. 


\section{1. ÚVOD}

Tento článek přinese popis rekonstrukce stř́brných píštal nalezených v urském pohřebišti v soukromém hrobě PG/333, který objevil Sir Leonard Woolley v roce 1926. Ve srovnání s harfami a lyrami, které zde byly objeveny také, jsou v povědomí odborné veřejnosti spíše ve stínu zájmu, ačkoliv jejich význam není o nic menší nežli tyto strunné skvosty. Záměrně se zde vyhýbáme termínu „zdvojené flétny" nebo „zdvojené pištaly“, přestože jsou v řadě zahraničních publikací takto označovány. Tyto dechové hudební artefakty se nalezly pouze ve fragmentárním stavu, což znamená, že s těmito částmi lze různě operovat, a proto název „zdvojená“ se dá rozšiřrit o další varianty, které v tomto článku budou uvedeny. A tak se nabízí otázka: Jde skutečně o zdvojenou píštalu či flétnu, jak uvádí nejedna odborná publikace?

Prostřednictvím analýzy ikonografických nálezů či hudebních artefaktů objevených také $\mathrm{v}$ jiných regionech si ukážeme podobné typy dechových nástrojů, abychom lépe pochopili konstrukci neúplného nástroje. Nenahradí však klíčovou komponentu, kterou představuje plátek neboli strojek, protože ovlivňuje ladění, barvu či celkovou kvalitu zvuku nástroje vůbec. Z tohoto důvodu rekonstrukce nabídne experimenty s několika typy rezonátorů, čímž vzniknou různé varianty tónových řad, které se budou více či méně přibližovat nebo vzdalovat skutečnosti. Strojek neboli plátek se podle většiny odborníků vyráběl z rákosu, což je materiál, který se do současné doby nemohl zachovat. Proto původní materiál v experimentu 2 bude suplovat 3D tisk. Díky této moderní technologii, lze pracovat se třemi možnostmi této komponenty, ovšem kvalitní př́rodninu zvukově rozhodně nenahradí. Tuto substituci provedeme $\mathrm{v}$ př́ípadě experimentu píśtaly $\mathrm{s}$ labiem. Plátky se pokusíme vyrobit z př́rodního materiálu, který se používá dodnes, a tím je "arundo donax". Dř́ve se ze stébel u tohoto druhu rákosu vyráběl papyrus i hudební nástroje. Dosud je tato přírodnina využívána $\mathrm{k}$ výrobě plátků pro aerofony (Hoskovec 2008).

Vzhledem k tomu, že problematika realizací hudebních nástrojů patř́ do experimentální archeologie, je nutné řídit se zásadami platnými pro experiment. To znamená, že musíme popsat jakým způsobem a z jakého materiálu byly vyrobeny a stejně aplikovat při rekonstrukci. Protože Mezopotámie patř́i k oblasti, kde symbolika a rituály hrály důležitou roli, nevynecháme ani tento aspekt.

\section{VÝCHOZÍ ARTEFAKTY}

Dnes se tento dechový hudební nástroj ze stříbra nachází v University of Pennsylvania Museum of Archaeology and Antropology pod současným identifikačním číslem B17554B (viz Obrázek 1). Časově spadá do období ranědynastického, přibližně do roku 2450 př. n. l. Při porovnávání výzkumů tohoto významného artefaktu je vidět posun názorů na tyto nálezy stř́ibrných trubic, který si nyní připomeňme. Objevitel L. Woolley se domníval, že se jednalo o jakási pítka či brčka, která byla součástí tamějšího smrtícího rituálu, v rámci něhož měli všichni účastníci požít jedovatý nápoj. Posléze se ovšem zjistilo, že tato pítka mají otvory, jaké lze vidět na dechových nástrojích, at už se jednalo o píštaly či flétny. Tyto trubice se nenašly celé, 
Obrázek 1: Fragmenty stříbrných píštal z Uru

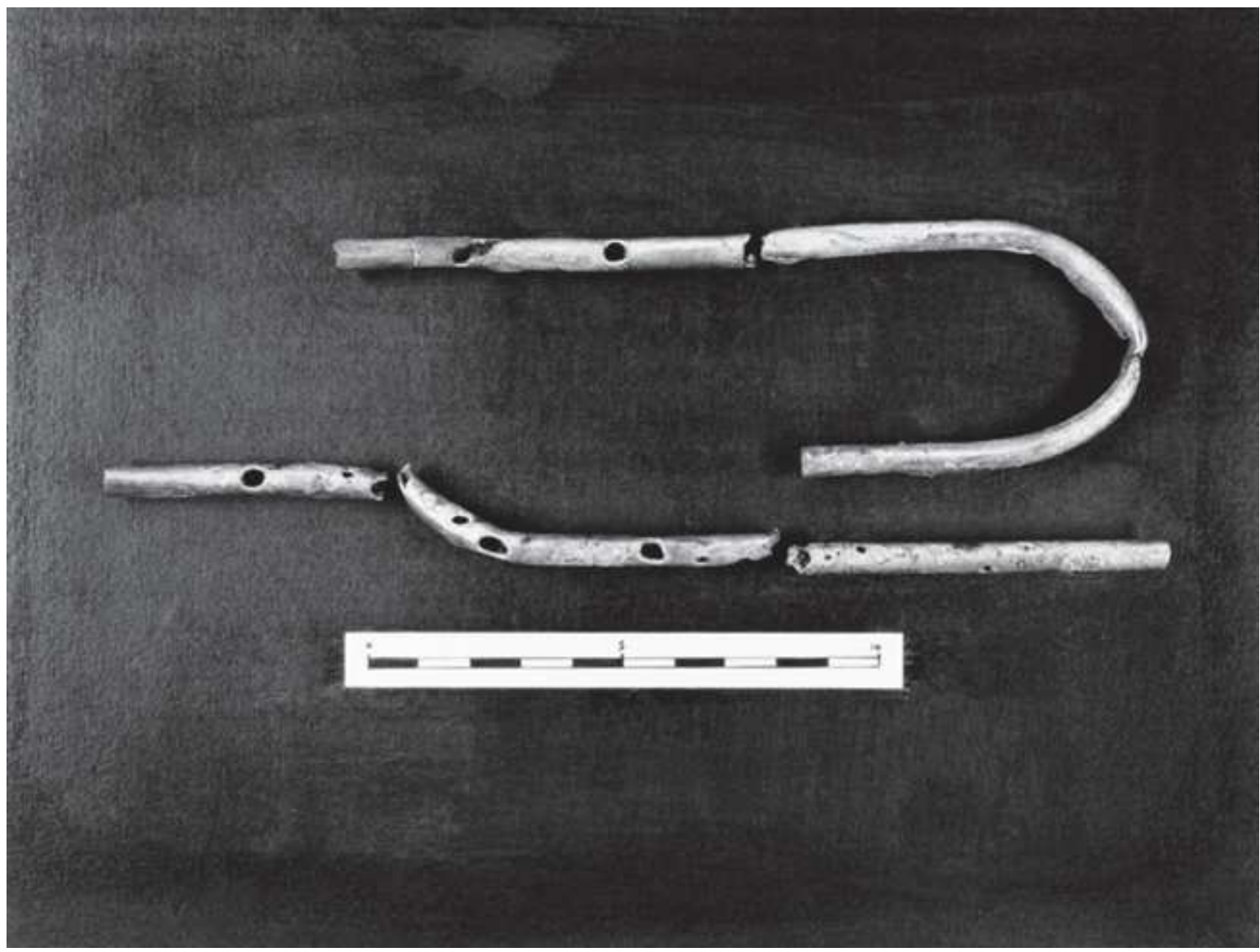

Zdroj: Penn Museum (n. d.)

nýbrž se našly v neúplném stavu. Artefakt čítal pět fragmentů. L. Woolley ovšem těmto nalezeným drobnějším kusům věnoval jen málo pozornosti (Lawergren 1998: 121-132).

O pár let později jako první projevil zájem o nástroje J. Galpin. Nálezům se věnoval velmi intenzivně, ale častá manipulace s artefakty způsobila, že původních pět fragmentů se ještě rozlomilo celkem na 17 kousků. To se stalo ve snaze nástroj vyčistit, aby se znovu blýskal. Předpokládal, že se jedná o dvě identické píštalky s jazýčkem. Odvodil z nich tuto tónovou řadu: C-D-E-F-G-A (Lawergren 1998: 121-132).

Výsledky výzkumů přehodnotil K. Sachs, který se odvolává na mezopotámský tonální systém. Upozornil, že se nesmí přehlížet zlomová místa, jež zanechávají stopy po dalších otvorech. On se domnívá, že jedna z trubic má tři otvory a délka trubice je $25 \mathrm{~cm}$. Chybí zde jazýček, bez kterého nelze tónovou řadu přesně vytyčit. Vzdálenost mezi otvory je 2,5 cm. Vyvozuje tyto poměry 10:9:8:7, které po převedení na centy dosahují těchto výškových frekvencí: $182-204-231$. Ty vyvodil pouze u jedné z trubic (Lawergren 1998: 121-132).

Dlouho se těmito nástroji nikdo nezabýval, až v roce 1969 J. Rimmerová přichází s názorem, že se jedná o dvojitou flétnu s dvojitým jazýčkem. Jedna z trubic měla čtyři otvory a druhá měla otvor jeden. Ačkoliv tato interpretace také nebyla přesná, přinesla již jedno důležité zjištění, na němž se shodují i další 
odborníci. Nástroji chybí jazýček neboli strojek, který se nedochoval, protože byl pravděpodobně vyroben z rákosu. Totéž potvrzuje i B. Lawergren, kterému se podařilo opět spojit 17 fragmentů nástroje $\mathrm{v}$ původních pět nalezených, a zároveň potvrdil myšlenku, že bez jazýčku lze těžko determinovat stupnici, a tudíž jakákoliv rekonstrukce bude jen pravděpodobnou, protože první tón z řady vznikne na základě stanovené délky jazýčku (Lawergren 1998: 121-132). On sám, přestože jeho interpretace je považována za nejzdařilejší a nejvíce akceptovaná současnými odborníky na mezopotámské tonální systémy, zdůrazňuje, že jeho přínos spočívá pouze v sestavení 17 fragmentů v pět původních. „Právě jsem identifikoval odlišné segmenty pištaly a označil jsem je. Tato identifikace představuje hlavní výsledek tohoto pojednáni “ (Lawergren 1998: 122). Nicméně B. Brown považuje tuto myšlenku za velice skromnou, a i když s tvrzením B. Lawergrena souhlasí, zároveň nabízí jedno z možných alternativních řešení. To vychází z antropologických studií hudebních nástrojů typu ,launeddas“ z oblasti Sardinie, Íránské „neyjoffi“ a východoafrické „begeny“ (Brown 2002: 3). Prostřednictvím hloubkových studií výše zmíněných tonálních systémů se pokusil tento nástroj naladit.

Nástroj typu „launeddas“ je dřevěný dechový nástroj charakteristický pro ostrov Sardinie. Jedná se o ztrojenou trubici, kde jedna slouží jako „bzučák" a dvě další hrají melodie v terciích a sextách (Kroll et al. 1968: 52). Íránská „neyoffi“ je velmi tenká a dlouhá píštala a její typová podobnost se přisuzuje nástrojům existujícím již od predynastického období v Egyptě. Takto staré aerofony ale ukazují, že v této době možná ještě neměly otvory. V evropské hudbě ji označujeme jako aerofon typu „koncovka“. Frekvence tónu závisí na intenzitě proudícího vzduchu prostřednictvím odkrývání a zakrývání spodního otvoru.

\section{IKONOGRAFIE A ARCHEOLOGICKÉ NÁlezY AEROFONŮ Z BLÍZKOVÝCHOD- NÍHO REGIONU}

Ikonografické nálezy, které se pokusíme analyzovat, jdou napříč mnoha obdobími, a to od ranědynastického až do období helénského neboli zhruba od 3. tis. př. n. l. až do 4. st. př. n. l. Klíčová zobrazení pro naši rekonstrukci jsou z období ranědynastického tedy stejného, jako je doba vzniku stříbrných píštal. Těchto zobrazení máme $\mathrm{k}$ dispozici jen minimum. Jeden z nich je nález z perleti (Metropolitan Museum of Art n. d.), na které je obraz ženy hrající na dechový nástroj, jenž velmi připomíná pastýřskou píštalu s prstokladem v dolní části nástroje. Dobrý pozorovatel si rovněž všimne i ozdoby na hlavě, která se téměř shoduje s nálezy v Uru, což potvrzuje myšlenku tradice nejenom stejných typů hudebních nástrojů, ale třeba i stejný styl v oblékání.

Výjev zřetelně ukazuje, že nástroj nemá jazýček ani labium, tuto funkci zde nahrazují rty. Nález pochází z Nippuru z let 2600 až 2500 př. n. l. (viz Obrázek 2). Pokud si dobře spočítáme prsty na nástroji, což se dá z obrázku také vyčíst, můžeme usoudit, že otvorů bylo sedm nebo osm. Palec instrumentalista asi nepoužil. Nejedná se tedy ani o nástroj typu „aulos“ nebo „arghul“.

Stejný typ nástroje z období akkadského, z roku 2400 až 2200 př. n. l. vidíme na pečetním válečku BM 102417 (viz Obrázek 3), ovšem jen ve velmi nejasných obrysech. Přesto je vidět, že postava nalézající se v horní levé části blíže ke středu 
Obrázek 2: Nález z Nipurru 2600-2500 př. n. l. Obraz ženy hrající na jednoduchou piśtłalu bez labia, bez jazýčku

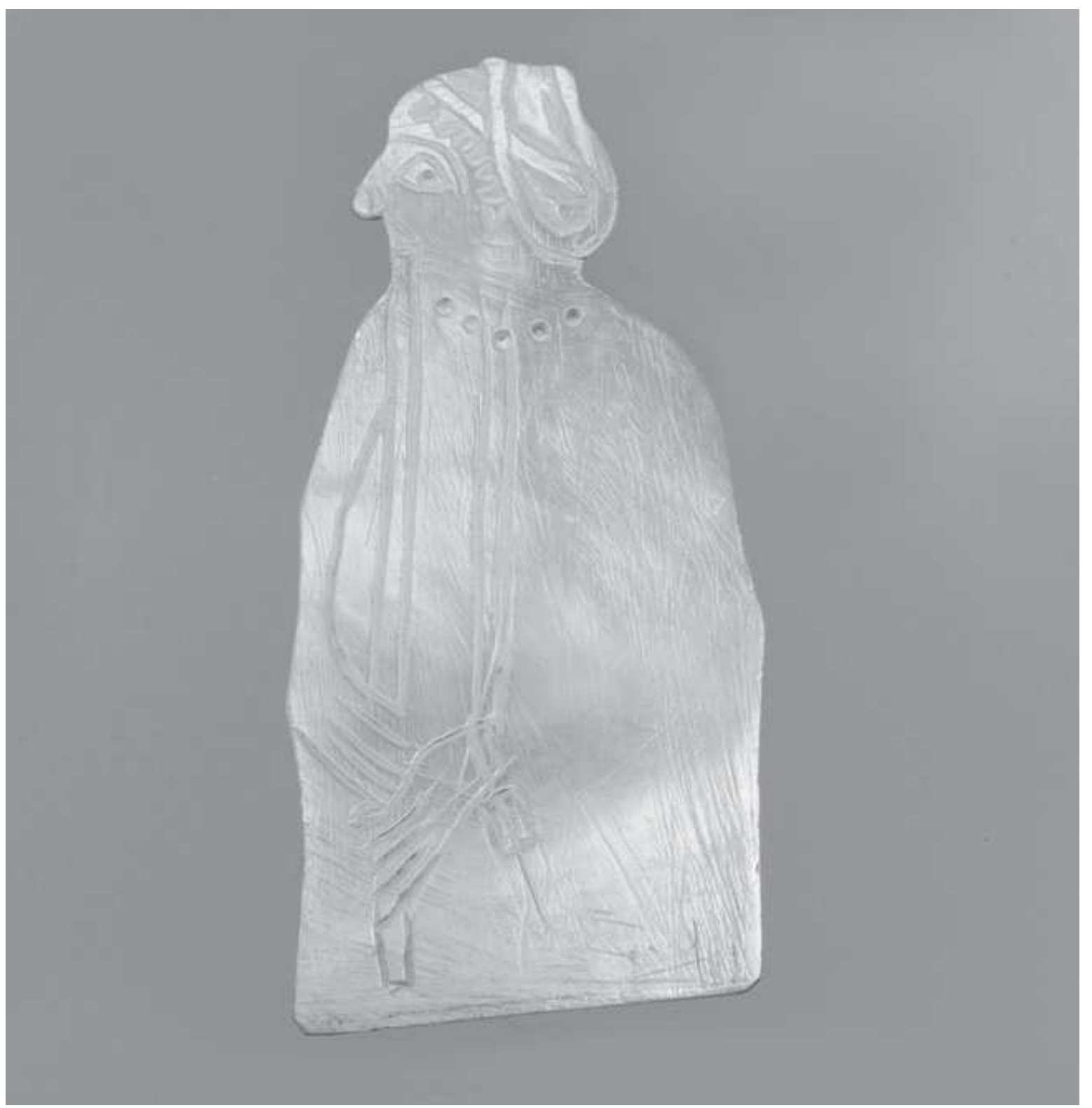

Zdroj: Metropolitan Museum of Art (n. d.)

hraje na dechový nástroj. Polohu hracích otvorů už nelze z tohoto obrázku určit, ale i v tomto případě nám poskytuje významnou informaci. Instrumentalista nehraje na zdvojený hudební nástroj.

Další velmi staré aerofony se nám dochovaly na paletě dvou psů z chrámu Hierakonpole v Egyptě z let 3200 až 3050 př. n. 1. (viz Obrázky 4a a 4b). Vidíme tu obrázky různých zvírat, možná maskovaných instrumentalistů, z nichž jeden hraje na dechový hudební nástroj, s otvory v dolní části, stejně jako je tomu u sumerských obrazů. V souvislosti s našimi píštalami z Uru, na zobrazeném dechu vidíme několik zdvojených zářezů. Tato dvojitá čára při hlubším zkoumání se nachází i na našem analyzovaném artefaktu. Podle některých odborníků egyptské flétny měly 3 až 8 


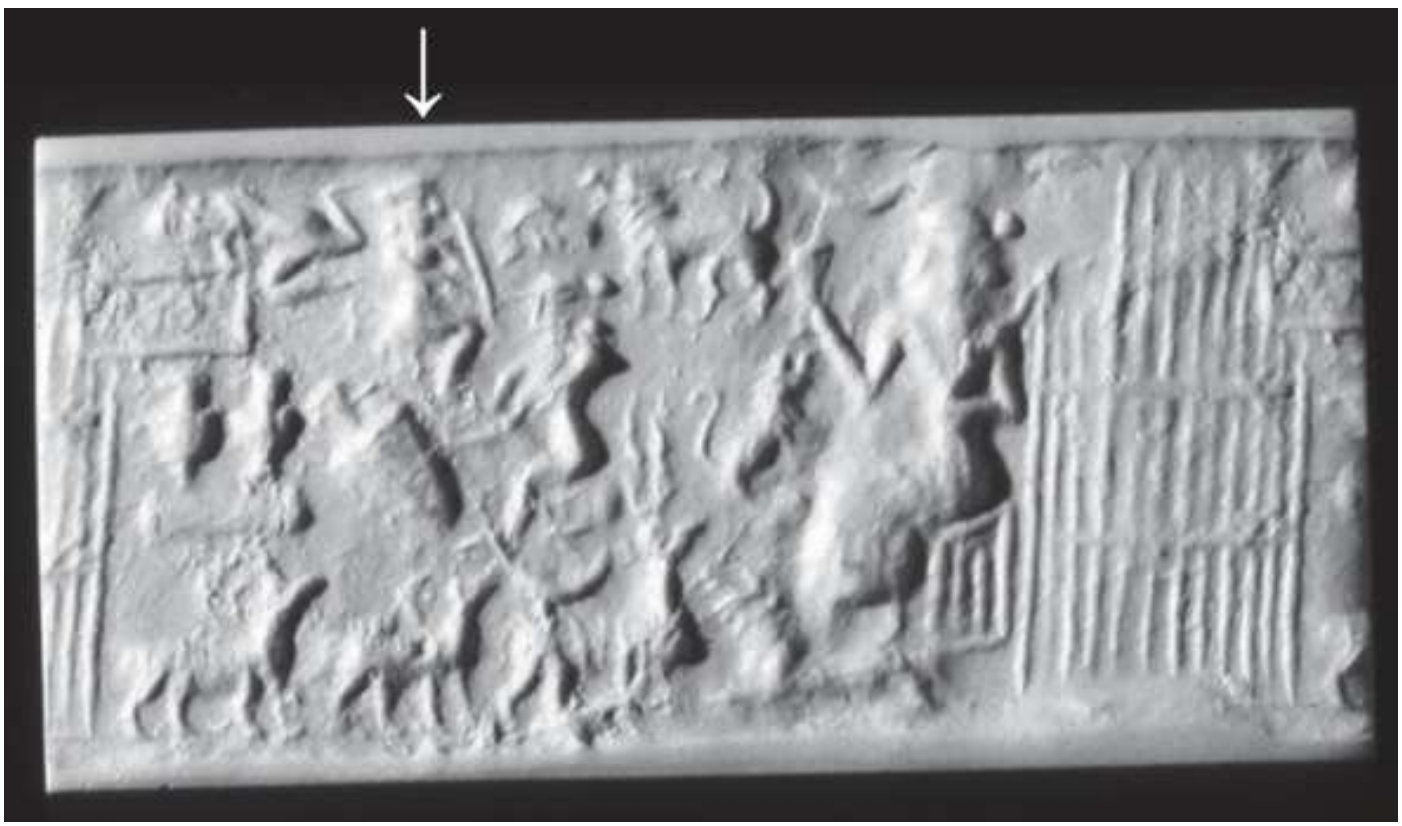

Zdroj: Flutopedia (2018)

otvorů a vyráběly se z rákosu (Verner, Bareš, Vachala 2007: 182). Paletu najdeme $\mathrm{v}$ Ashmolean Museum.

Ikonografie aerofonů taktéž z Egypta obohatí reliéfy z Théb, z Karakhamunovy hrobky TT23 pocházející ze III. a IV. dynastie (2686-2125 př. n. 1.) (Shaw 2003: 498) a z V. dynastie (2494-2345 př. n. l.), které patří do Staré říše. Zobrazení instrumentalisté používají tzv. koncovku o délce přibližně $1 \mathrm{~m}$. Zvuk vzniká skrze horní hranu nástroje. Pokud měl aerofon otvory, pak se jejich počet odhaduje na tři nebo čtyři (Pishikova 2014: 124). Ve srovnání s našimi artefakty jsou tyto nástroje delší, avšak společně s nimi mají tenký průměr. Doba vzniku se téměř shoduje s aerofony mezopotámskými.

Získáme-li co nejvyšší počet typově podobných aerofonů z doby přibližně stejné, případně starší, dopracujeme se tak s největší pravděpodobností k informaci, zda nález může být píštalou zdvojenou či dvěma samostatnými nástroji. Tímto způsobem se můžeme více přiblížit skutečnosti. Naším cílem je zamyslet se nad dosavadní rekonstruovanou variantou zdvojeného nástroje a přinést hypotézu o dvou samostatných píštalách, ačkoliv minimální množství zachovaných zobrazení z ranědynastického období vypovídá spíše proti ní. Vezmeme-li dobově starší či stejné reliéfy ze sousedních regionů, jakým je např. Egypt, pak i na nich vidíme píštaly jednoduché. Zdvojené se nacházejí na reliéfech z pozdějších období. Vycházíme z ikonografie aerofonů z doby přibližně stejně staré, tak jako se archeologické artefakty posuzují z hlediska jedné stratifikační vrstvy, ze kterých se pak vyvodí charakteristické znaky té či oné kultury.

Nálezy zdvojeného nástroje typu „aulos“ ze stejného časového horizontu, najdeme pouze na Kykladských ostrovech v podobě sošky držící zdvojenou píštalu, která časově spadá do let 2800 až 2300 př. n. 1. (Ancient History Encyclopedia 2012). Pokud by se dokázaly vztahy oblasti Kykladských ostrovů s Mezopotámií 
v období, o kterém hovoříme, pak by vskutku aerofony nalezené v Uru mohly být zdvojené píštaly. Ale i tak máme k dispozici jediný artefakt, ${ }^{1}$ což je minimální vypovídací hodnota o existenci zdvojených píštal v oblasti Středomoří a už téměř žádná ohledně přesunu do Mezopotámie. Lze jej nalézt v Archaeological museum of Athens.

Z doby ještě starší nacházíme dokonce píšttaly v Řecku v lokalitě Toumba Kremastis Koiladas (Chondrogianni-Metoki 2015) z dob neolitu. Nástroj z roku 5000 př. n. l. byl vyrobený z kosti a měl pět otvorů pro hraní, nerovnoměrně umístěných po celé délce. Nyní se vyskytuje v Archaeological Museum of Thessaloniki. I když jsou tyto artefakty odborníky označeny jako „auloi“ (viz Obrázek 5), nic nenasvědčuje tomu, že se na ně nehrálo jako na samostatné nástroje. Také se nacházíme v odlišném regionu, nikoli v Mezopotámii či na Blízkém východě vůbec.

Vývojově mladší období nám zanechávají nálezový fond ve formě ikonografie poněkud bohatší. Od 21. st. př. n. 1. až do roku 30 př. n. l. se tu zdvojené aerofony vyskytují poměrně hojně, at už chceme aerofon typu "argul" nebo "aulos". $\mathrm{V}$ některých případech se tyto dva dechy ${ }^{2}$ obtížněji rozlišují. Řada nálezů pochází z Egypta, Mezopotámie, Sýrie, Anatolie nebo ze Středomoří jako například z Kypru či dalších oblastí.

Ze starobabylonského období mezopotámských dějin se dochovala soška hudebnice hrající na zdvojenou píśtalu. Byla nalezena $v$ povodí řeky Dijály a datum vzniku se odhaduje do let 2000 až 1600 př. n. l. Nyní se nachází v Oriental Institute Museum University of Chicago pod číslem DSC07339.

Z oblasti severní Mezopotámie z Asýrie máme k dispozici nemalý počet reliéfů, kde na řadě z nich jsou i hudebníci, kteří hrají na aerofony. Jako příklad lze uvést reliéf s hudebními motivy z Ninive z JZ paláce krále Sinacheriba z roku 705 až 681 př. n. l., kde v početném pochodujícím hudebním tělesu se vyskytují také ti, co hrají na nástroj typu „aulos“. Ze stejné lokality ze severního paláce krále Ašurbanipala II. z období o něco mladšího z roku 645 př. n. 1. (Collon 2008: 47-65) máme k dispozici dlouhé zdvojené nástroje typu „argul“. Odborníci hodnotí tento obraz jako orchestr v rámci zahradní slavnosti. Kromě těchto instrumentalistů vidíme i ženy hrající na lyru a harfu.

Další př́́klady aerofonů si vypůjčíme z Egypta. V hrobce Menny, ve které nalezneme i mimo jiných barevných reliéfů z let 1400 až 1390 př. n. l. také zobrazeného flétnistu předvádějícího hru na tenký dlouhý aerofon, u něhož není dost zřetelné, zda má vyvrtané otvory, či je zvuk vyluzován prostřednictvím nátisku ústy a zakrýváním a odkrýváním dolního otvoru nástroje.

Malby z Théb z 18. dynastie znázorňují spolu s dalšími hudebnicemi nástroj typu „aulos". Obraz byl objeven v hrobce Nebamuna (The British Museum 2017). Nyní se vyskytuje v British Museum pod identifikačním číslem EA37981. Egypt je bohatý nejenom na obrazy s dechovými nástroji, ale z doby vlády Ptolemaiovské dynastie z let 305 až 30 př. n. 1. archeologové objevili v Alexandrii 2 píštaly jako další hudební artefakty. V Alexandrii jsou také v Graeco-Roman Museum umístěny.

\footnotetext{
${ }^{1}$ Předpoklad jediného artefaktu vychází ze zdrojůn, které byly k dispozici.

${ }^{2}$ Dechy - další označení pro aerofony.
} 
Obrázek 4a: Paleta dvou psů z chrámu Hierankopole, 3200-3050 př. n. l.

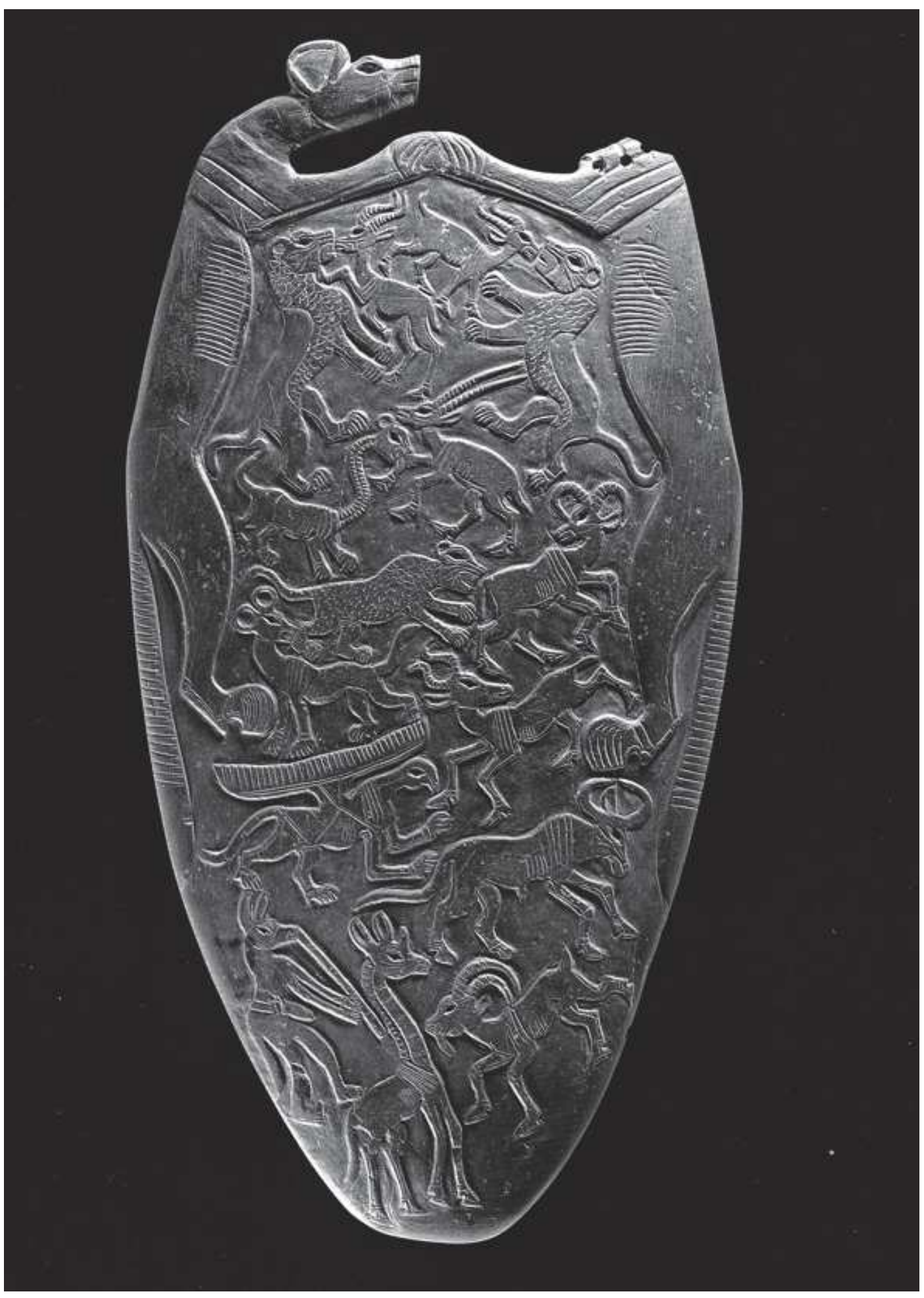

Zdroj: Virgilio (n. d.) 
Obrázek 4b: Paleta dvou psů z chrámu Hierankopole, 3200-3050 př. n. l., detail instrumentalisty

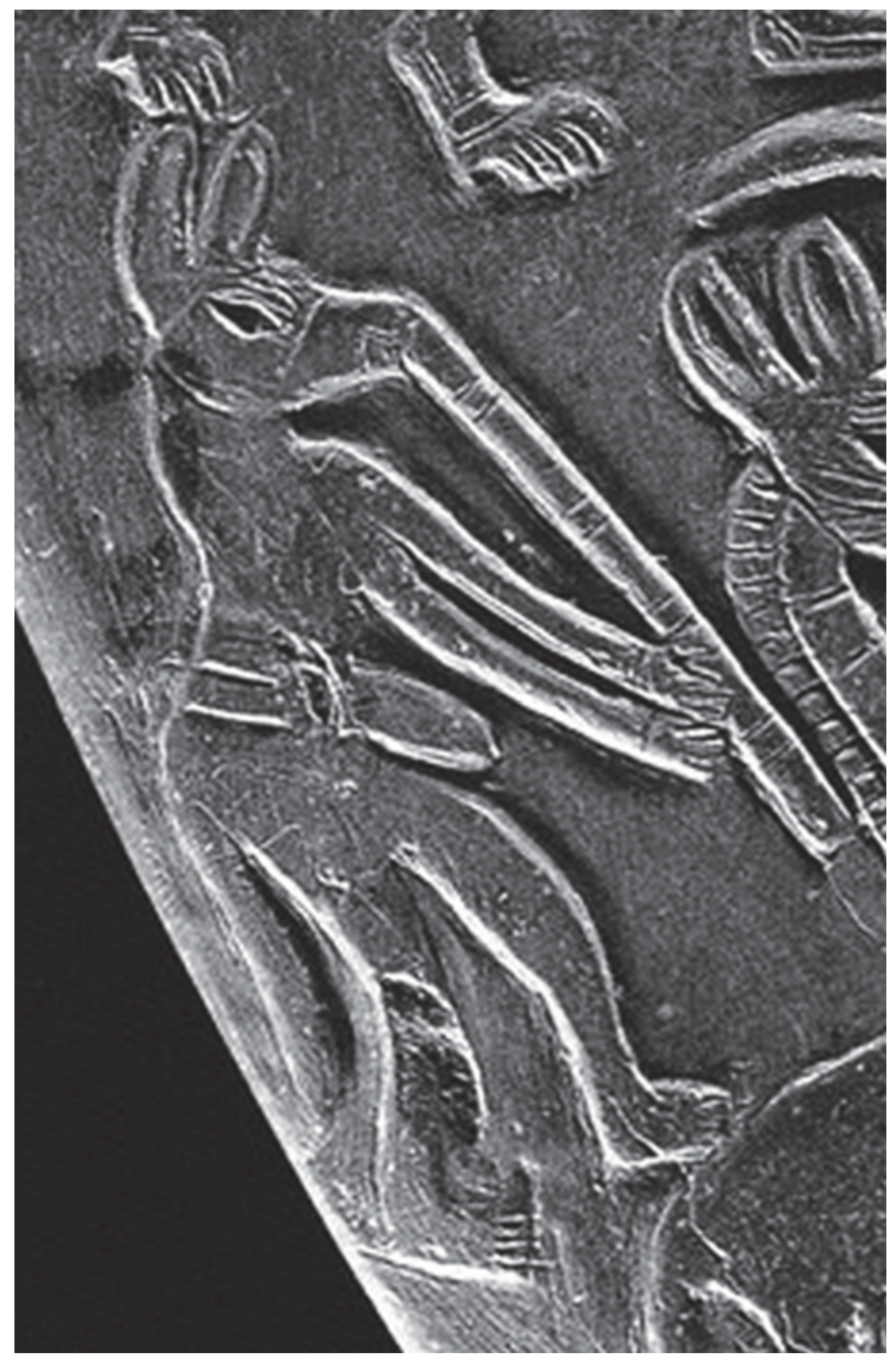

Zdroj: Virgilio (n. d.) 
Obrázek 5: Hudebni artefakty typu „píštaly“ z Řecka (lokalita Toumba Kremastis Koiladas) z roku 5000 pŕ. n. l.

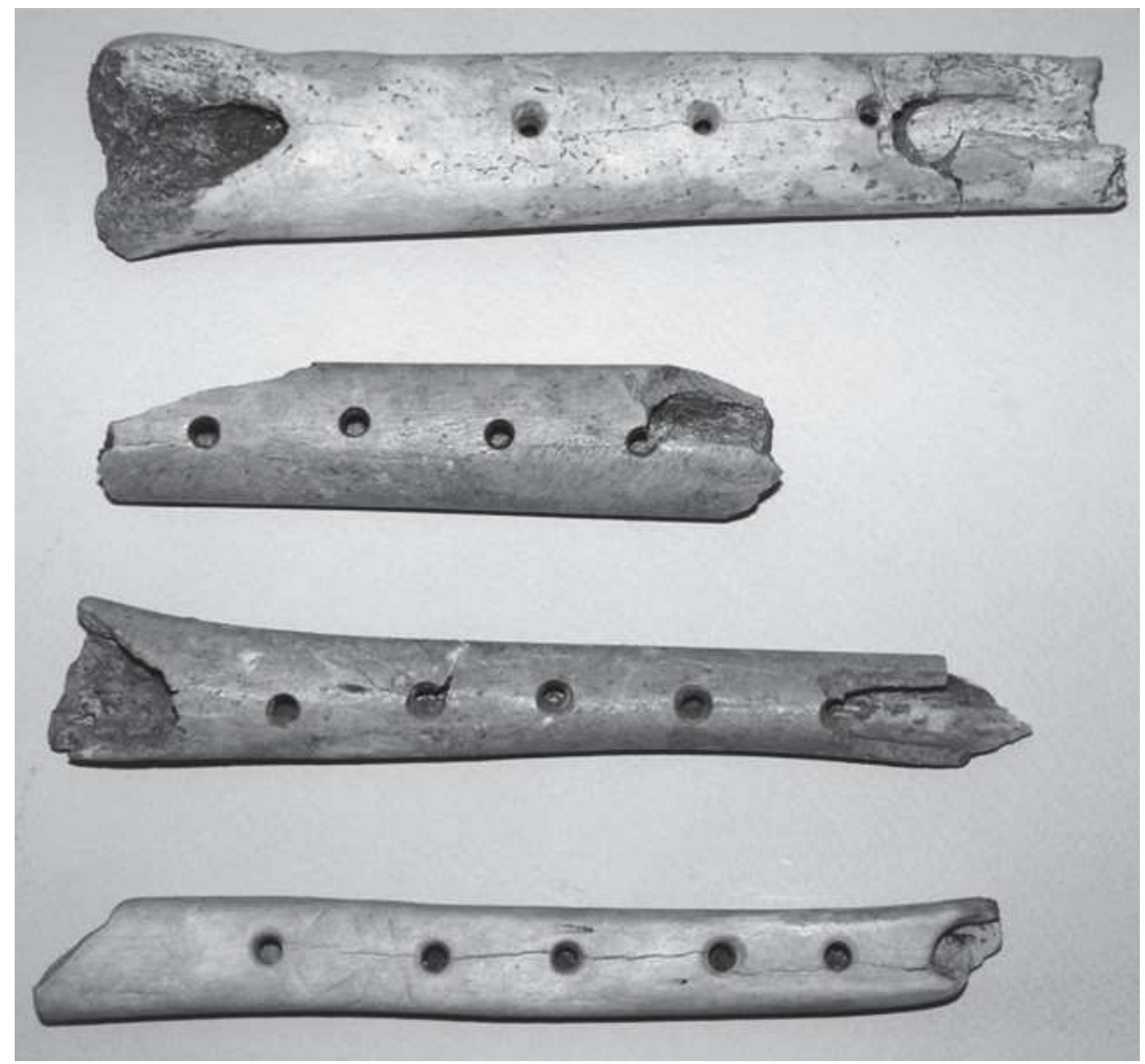

Zdroj: Chondrogianni-Metoki (2015)

Z Izraele si představíme dva rozlomené fragmenty píštal, které byly vyhodnoceny jako nástroj typu „aulos“. Části nástroje byly objeveny v jedné z rezidencí z doby římského impéria v oblasti Gezer (Braun 2002: 226). Podobné nálezy stejného období máme také ze Samaří (IAA35.3548) nebo z hory Sión z Jeruzaléma (IMJ 94.124.94) (Braun 2002: 225). Z ikonografie se dochoval kultovní stojánek se soškami hudebníků z Ashdodu z přelomu 11. až 10. st. př. n. l. (Braun 2002: 134) Jeden z nich hraje na aulos. Podobný artefakt se stejným typem aerofonu uvidíme i v Achzíbu z 8. až 7. st. př. n. l. (IAA 44.56) (Braun 2002: 135). Všechny tyto artefakty se nacházejí v The Israel Museum v Jeruzalémě.

Ikonografické nálezy aerofonů nechybí ani v Anatolii na reliéfech v Karatepe (Koç University 2017) v jižním Turecku, ve venkovním muzeu Karatepe-Aslantaş. I zde máme zdvojené píštaly. To, zda se jedná o argul nebo aulos, se obtížně rozlišuje. Obě varianty jsou možné. 
Výčet zobrazení popisovaných zdvojených aerofonů se zvyšuje s nadcházejícími obdobími, a to v nejrůznějších oblastech, nejenom v blízkovýchodním regionu, ale i ve Středomoří, odkud je možné monitorovat jejich původ i rozptyl do dalších regionů a lze pozorovat úbytek jednoduchých píštal, které spíše vidíme v období starších, ačkoliv nacházíme jen minimum obrazů či sošek nebo terakot, které tuto hypotézu potvrzují. Dokládají nám to i reliéfy z období Nové říše z Egypta, kde jednoduché flétny jsou nahrazeny spíše loutnou (Pishiková 2014: 123), která se v tuto dobu objevuje. Tam, kde v dobách starších byly dlouhé píštaly s hranou tzv. koncovky, jsou nyní nástroje kratší a zdvojené. Neznamená to však, že se na jednoduché píštaly nehrálo, jen upozorňujeme na jejich výrazný úbytek.

\section{MOTIV RÁKOSOVÝCH PíŠŤAL V MEZOPOTÁMSKÉ LITERÁRNí TRADICI}

Truchlení, nářky, zármutek ve spojitosti s flétnami v př́ibězích Blízkého východu, stejně tak jako v legendách jiných částí světa, nacházíme velmi často. Snad kvůli proudícímu vzduchu, který vytváří v nějaké dutině zvuk. Tento vzduch připomínající naříkání jako by se vztahoval k duši zemřelého, která odlétá do končin podsvětní říše, odkud není návratu či se naopak může znovuzrodit díky zvukům, které tento nástroj vyluzuje. Proto se domníváme, že její využití souviselo s pohřebními rituály a možná i s ročními přírodními cykly.

O píštalách z rákosu se zmiňují také některé příběhy sumerské i akkadské literární tradice. Například v příběhu Sestup Inanny do podsvětí. Dočítáme se tam o tom, jak démoni zajali jejího manžela, pastýře Dumuziho, kterému dle akkadské tradice polámali rákosovou flétnu, na kterou hrál (Wolkstein, Kramer 1983: 71). V části z cyklu Návrat matka Dumuziho plačtivě sděluje: „Srdce, které naříká, hraje na smuteční flétnu z rákosu" (Wolkstein, Kramer 1983: 86).

Kurt Sachs nabízí myšlenku, že by flétna mohla souviset i s plodností a úrodností země, protože je spjatá s pastýři, kteří na tento nástroj hráli (Sachs 2006: 44). Příběh o Inanně a jejím choti, který byl pastýř hrající na flétnu z rákosu, nám tento motiv připomíná. Jeho odchod do podsvětí tu symbolizuje přírodu chystající se na období klidu a příchod jara tu znamená, že se bůh Dumuzi opět navrací. Motiv mizejícího a znovu přicházejícího boha představuje pravidelně se střídající roční období. Sestup Inanny do podsvětí však může také ukazovat, že zemi postihla určitá katastrofa $\mathrm{v}$ podobě sucha nebo záplav či války. To vše ve staré Mezopotámii nazývali chaosem a s odchodem těchto pohrom zavládl opět řád, což znamená, že se bohyně Inanna znovu vrací na své místo.

\section{VARIANTY REKONSTRUKCE PÍŠŤAL Z URU}

Z nalezených fragmentů nelze popřít, že tu máme co dočinění se dvěma píštalami bez existence plátku. ${ }^{3}$ Protože se nám nedochovala nejdůležitější komponenta, nemůžeme určit, jestli se jedná o nástroj plátkový či píštalu retnou s labiem. Tato část je ovšem klíčová pro určení tónového modu. Proto jsme se pokoušeli experimentovat s plátkem i labiem. ${ }^{4}$ Obrazy z období ranědynastického se podobají spíše

\footnotetext{
${ }^{3}$ Strojek - má více termínů, někde se označuje jako jazýček, někdy také jako plátek.

${ }^{4}$ Labium - zvuková hrana, která rozechvívá vzduch, je zdrojem zvuku u píšteal retných.
} 
pastýřské píštale nebo nástroji typu koncovka. Mějme na zřeteli, že obrazy z období ranědynastického a akkadského poskytují informace jen o tvaru a prstokladu, a to jen v některých případech. Popis experimentů je dán podle doby, kdy byly v rámci empirických výzkumů zhotoveny.

Varianta první je nástroj typu „argul“, jako variantu 2 předložíme „píštalu retnou s labiem" a jako poslední nabídneme rekonstrukci dvou samostatných aerofonů typu „pastýřská píštala“. Byla zde zvažována i varianta nástroje typu „krumhorn" neboli křivý roh, který také patří mezi nástroje plátkové náležející skupině dřevěných nástrojů, jehož tvar připomíná ohnutou trubici. Tónový rozsah nástroje nepřesahuje nónu (Oling, Walisch 2004: 104). Nóna je interval sestávající z oktávy a sekundy. Tvoří ji devět tónů. ${ }^{5}$ Argumentem pro tento předpoklad je tvar artefaktu, který se nám dochoval v zaoblené podobě, poněvadž se všeobecně předpokládá, že tato zakřivení byla způsobena deformací půdy, ve které se po tisíciletí nacházel. J. Vyšata, strojní inženýr v rámci diskuse podpořil tuto myšlenku slovy: „Vytvořit pravidelné zaoblení u kovové trubice, jaký je vidět na fotografii artefaktu, je velice obtížné. Tlak hlíny pưsobící na artefakt po tak dlouhou dobu, samozřjmě deformaci způsobí, nikoli ovšem do pravidelného zaobleného tvaru" (Vyšata 2017: nestr.). Po zhodnocení veškeré dostupné ikonografie a písemných pramenů s aerofony jsme ovšem tuto variantu vyloučili. Žádná zobrazení ani písemné prameny z doby, o které hovoříme, nenacházíme.

Nástroj typu „aulos“ je hudební dechový nástroj s mírně zaobleným plátkem, který je napojen na trubici (viz Obrázek 6) cylindrického nebo kónického tvaru s různým počtem otvorů pro hraní (Oling, Walisch 2004: 96). Tyto trubice jsou dvě a každá má samostatný dvojitý plátek mírně vypouklého tvaru. V některých případech mohou být tyto trubice spojeny, jindy odděleny, ale hraje se na obě současně. Byl používán mimo již zmiňovaných oblastí především ve starověkém Řecku a jeho původ se předpokládá ze Středomoří. Jedno z jeho dalších označení je „lybikos lotos“. Dalším synonymem tohoto dechu je „kalamos“. Materiálem použitým na jeho výrobu byl obvykle rákos, lotosové dřevo, kost, zimostráz, ale př́́ležitostně i kov jako bronz nebo měd' (Ancient History Encyclopedia 2012).

Nejstarší písemné prameny pocházejí z Řecka a zmiňuje se o nich Homér v souvislostmi ještě s dalšími událostmi, které se odehrávaly okolo roku 1000 př. n. 1 . (Montagu 2007: 74). Je vhodné uvést jeho popis pro srovnání s nástrojem typu „argul“. Od nástroje typu „aulos" se liší tím, že dvě trubice jsou vzájemně spojené a přilehlé. Nástroj se dodnes využívá také v arabských zemích. Počet otvorů pro hraní a délka trubic se různě liší. Existuje již od dob antiky a od té doby zůstal téměř nezměněn. Jen musíme připomenout, že $\mathrm{v}$ některých případech je obtížné z ikonografie určit, zda hudebník hraje na argul nebo na aulos. Argul patří také mezi nástroje dvouplátkové.

Pastýřská píštala je př́íklad píštaly retné a bude rovněž zařazena do našich experimentů. "U pištal retných (labiálních) zvuk vzniká na rtu pištaly, tj. na ostré hraně obrácené proti úzké štěrbině, z níž vychází proud vzduchový [...]. Na rtu pištaly vznikaji rozmanité tóny, dle toho, jak jest ret upraven, jaká jest intenzita proudu vzdušného apod." (Otto 1902: 801).

${ }^{5}$ Nóna - malá nóna má 13 půltónů, velká nóna 14 má půltónů. 
Obrázek 6: Nástroj typu „aulos “

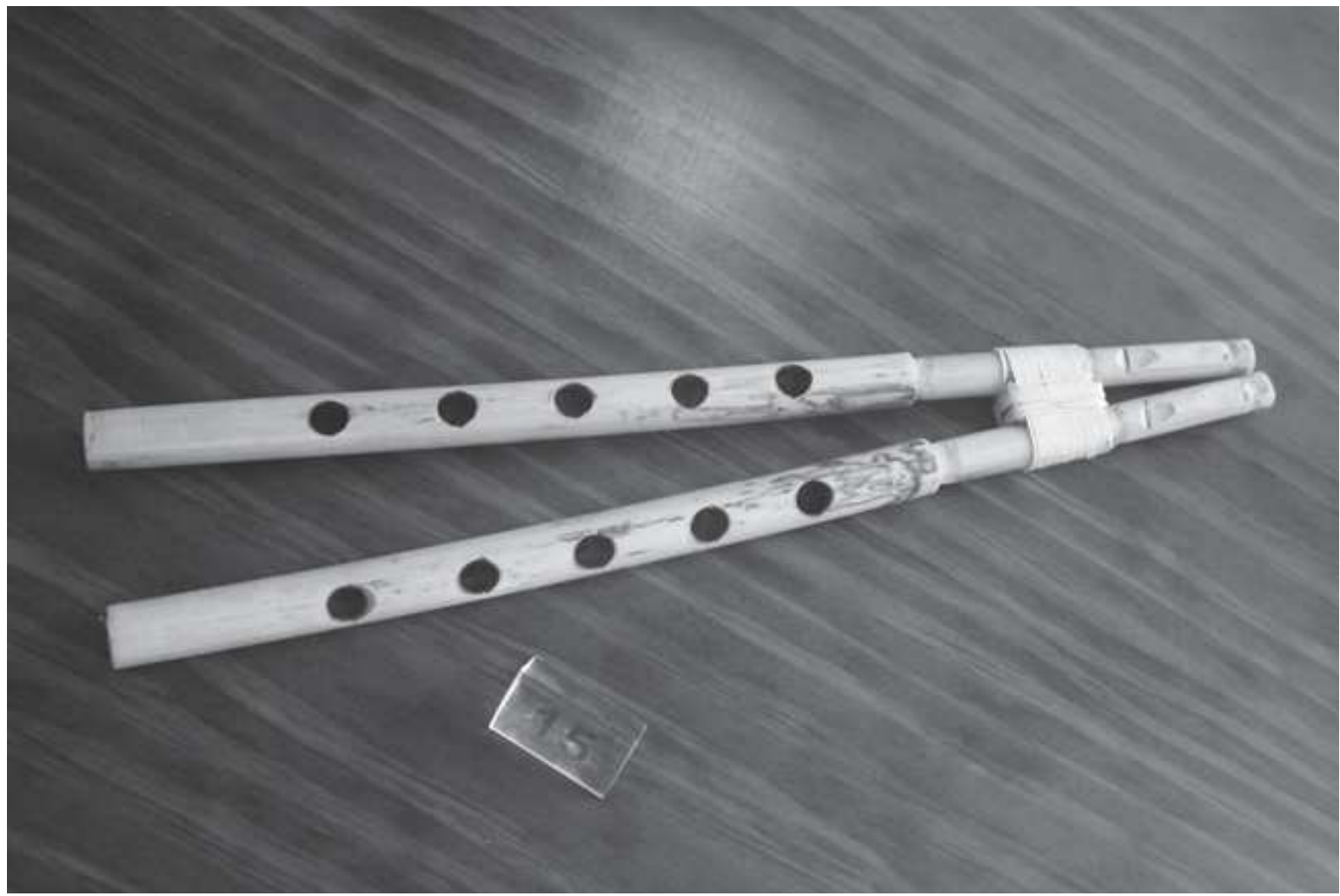

Zdroj: Ancient History Encyclopedia (2012)

\section{POPIS REKONSTRUKCE STŘíBRNÝCH PÍŠŤAL}

Než začneme s popisem provedených experimentů, je vhodné shrnout veškeré aspekty, bez nichž by se výroba nástroje jen obtížně realizovala. První zahrnuje tvar, průměr, délku, vnitřní vrt ${ }^{6}$ a materiál fragmentů artefaktu. Informace byly získány na základě fotografií z University of Pennsylvania Museum of Archaeology and Antropology. Druhý aspekt hledá typově podobné aerofony podle ikonografie zejména z období ranědynastického, ačkoliv je nutné akceptovat zobrazení i z období mladších a využít tzv. reverzní analýzu kvůli nedostatečnému nálezovému fondu hodnoceného období. Poslední hledisko se zabývá technologií výroby trubic ze stříbra.

Rekonstrukce by měla na základě zásad experimentu splňovat některé podmínky, které z časových důvodů ovšem nemohou být dodrženy. Například získat stř́ibrnou slitinu prostřednictvím původní technologie, protože lze předpokládat, že stř́ibro použité $\mathrm{k}$ výrobě trubiček jako hudebních nástrojů nebylo pravděpodobně zcela čisté. $\mathrm{V}$ rámci řešení realizace urských aerofonů se přistoupilo na takové pracovní postupy, které bezprostředně souvisely se zvukem nástrojů. Proto bylo nutné pracovat s plechy, jejichž struktura povrchu se co nejvíce přibližuje povrchu plechu analyzovaných stříbrných trubic. Zde vypomohly i jiné kovové artefakty (viz Obrázek 7), taktéž z urského pohřebiště.

\footnotetext{
${ }^{6}$ Vnitřní vrt - označení průměru dřevěných aerofonů, tloušttka stěny nehraje žádnou roli ani z hlediska barvy ani z hlediska výšky tónů.
} 
Obrázek 7: Zlatá spona z pohřebiště z Uru stočená do trubičky, 2600-2400 př. n. l.

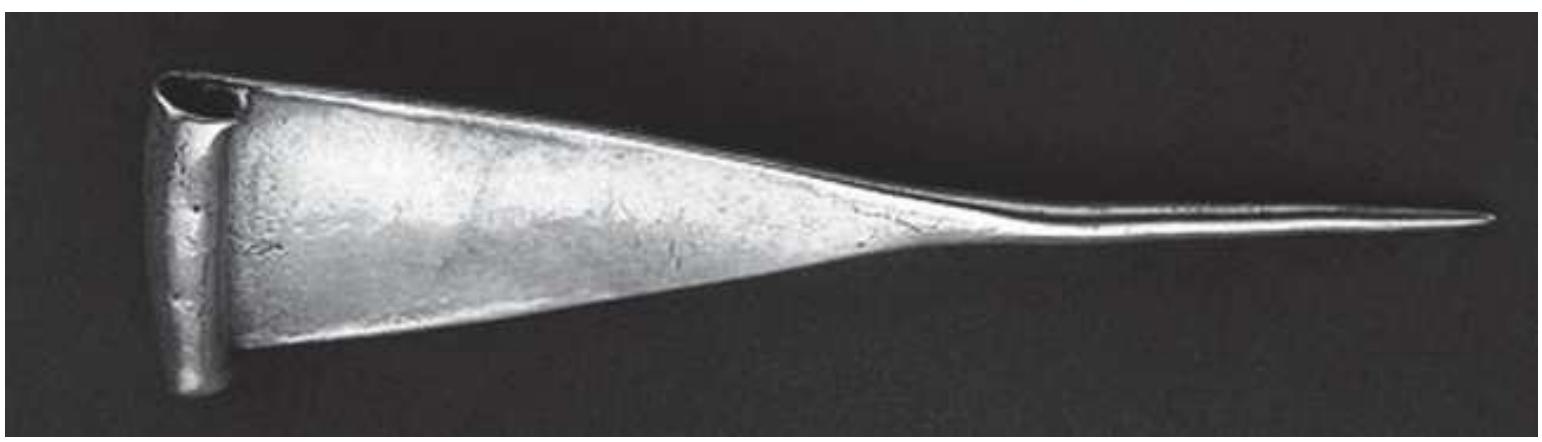

Zdroj: Traveltoeat (2014)

Obrázek 8: Nástroj typu „argul“

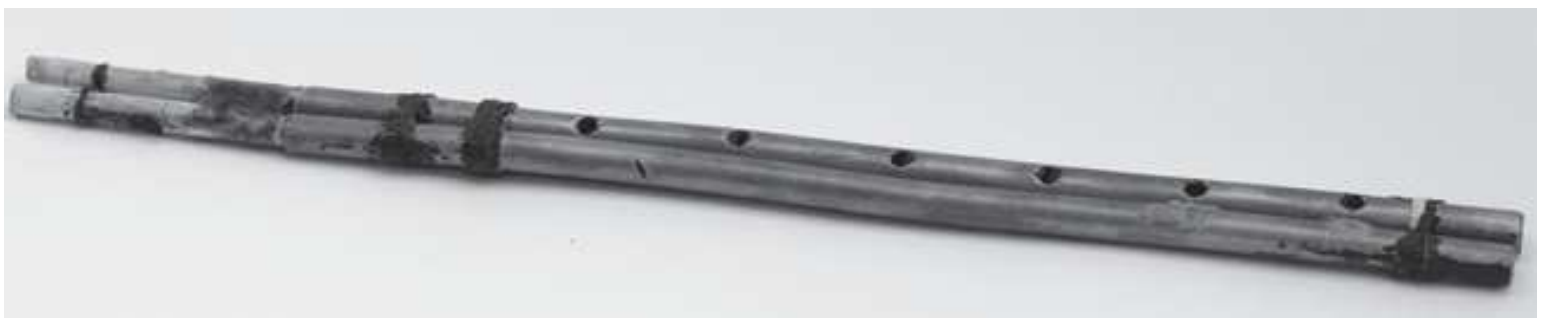

Zdroj: Kašpařík (2016)

Z nástrojů bylo využito malé kamenné kladívko, jehož prostřednictvím se dokázal vytepat i velmi tenký plech vysoké kvality. „Nejen lidé z neolitu ovládali technologie, mezi které patři i tepání, ohýbání, řezání, broušení a leštění, ale $i$ Sumeřané disponovali schopnostmi, jako je žíhání, tavení a odlévání kovư" (Scheel 1989: 8). Následující kapitoly se vztahují k jednotlivým experimentům. Provedli jsme celkem tří, ovšem variant se nabízí více, co se délky jazýčků týká. Ovšem i délka této části má své omezení, protože se instrumentalistovi musí vejít do úst tak, aby se na píštalku dalo hrát.

\subsection{EXPeriment 1 (VIZ Obrázek 8)}

Tento experiment byl proveden pod vedením J. Kašpař́íka v rámci Empirického výzkumu 2 2015/2016, který zde významně přispěl svými nápady a návrhy. Stejně jako B. Brown nepochybuje o tom, že popisovaný hudební artefakt může být plátkový, a od tohoto základu se experiment 1 dále odvíjel. Před popisem prvního experimentu je vhodné připomenout, že rozměry artefaktu uvedeme jen v prvním př́ípadě, protože ostatní pokusy s trubicemi operují se stejnými parametry. Není tedy důležité znovu opakovat stejné údaje. Při samotné výrobě došlo k nepatrným odchylkám, což by mělo mít na kvalitu zvuku jen minimální vliv, ovšem ladění už tyto nuance ovlivnit mohou.

Během výzkumu jsme podrobně studovali zdroj a na základě zjištěných údajů jsme provedli nárys všech fragmentů trubic a jako puzzle zkoušeli vytvořit vhodné kombinace tak, aby z nich vyplynul reálný nástroj. Náčrtek zahrnoval délku nástroje, průměr každé z trubic, průměr otvorů a vzdálenost mezi otvory. Fragmenty 
trubic nalezených v Uru byly do určité míry deformované, a také tu chyběl čtvrtý zlomek trubice mezi dvěma hmatovými otvory. Z těchto fragmentů se vyvodilo, že se jedná o dvě trubice stejné délky, z nichž jedna je pravděpodobně kratší o jednu rozteč dvou sousedních hmatových otvorů. Tato domněnka vychází z kratší délky spodní trubice. Při konzultaci s J. Kašpařŕkem vzešel předpoklad, že se jedná o dvojitou píštalu nazývanou dnes podle moderní hudební terminologie „argul“. Ten je v současném moderním arabském světě dobře znám a často se zde na něj hraje. K ozvučení jsme použili dvojitý jazýček z rákosu, protože je pohotovější ke hraní. Tento plátek neboli jazýček vzešel z dílny J. Kašpaříka. „Délka i konstrukce vsazeného jazýčku významně ovlivňuje ladění, to znamená, že výška tónu a výpočty vycházejicí pouze z parametrü trubice nejsou u tohoto typu nástroje smérodatné. Ladění, tóny či intervaly se u rekonstruovaného nástroje mohou lišit $i$ při drobných změnách stavu jazýčku“ (Kašpařík 2016: nestr.).

K rekonstrukci zvuku se připravily dvě měděné trubice, které podle zadání měly mít čtyři a tři otvory pro hraní. Délka každé z nich měla $240 \mathrm{~mm} .{ }^{7}$ Bez diskuse byly dány hotové trubičky požadovaných parametrů. Vnitřní vrt, který nejvíce ovlivňuje celkové ladění aerofonů, se pohybuje mezi 5 až $7 \mathrm{~mm}$. V rámci experimentu 1 každá z měděných trubiček měla průměr $5 \mathrm{~mm}$. Proč byly trubice měděné? Po vzájemné diskusi s J. Kašpařŕkem jsme usoudili, že měd' má výborné akustické vlastnosti výrazně podobné stříbru. Není tedy nutné z akustického hlediska pracovat se stř́brem, výsledky zvuku v souvislosti s náhradou materiálu se nemusí lišit (Kašpařík 2016). Stojí za zmínku, že tloušťka stěn trubic nehraje v souvislosti s intonací nástroje žádnou roli (Špelina 2017). ${ }^{8}$

Vzdálenost mezi otvory je další řešený problém, protože hudební artefakt z Uru se dochoval pouze ve fragmentárním stavu. Místa zlomů tak někdy znesnadňují stanovit, zda se v těchto místech vyskytoval otvor, či nikoli. J. Kašpař́ík předpokládal 6 otvorů, ačkoli z fotografií spíše vyplývá otvorů méně. Tady je nesoulad s počtem otvorů oproti fotografii daného artefaktu. Jejich průměr je dán spíše experimentálně tak, aby se vtěsnaly do šíře trubic a na nástroj se dalo hrát. Jejich průměr se pohybuje od 2,5 až 2,7 mm. Zajímavá je také připomínka odborníka na dechové nástroje M. Špeliny, že vzdálenosti mezi otvory jsou relativně velké a nepohodlné ke hraní, protože vyžaduje od instrumentalisty široké rozpětí mezi prsty odkrývající a zakrývající otvory (Špelina 2017).

Trubice 1 má mezi definitivním koncem a prvním otvorem $26 \mathrm{~mm}$, mezi prvním a druhým otvorem je $25 \mathrm{~mm}$, mezi druhým a třetím je celkem $23 \mathrm{~mm}$, mezi třetím a čtvrtým je $30 \mathrm{~mm}$. Z toho plynou celkem čtyři otvory ke hraní. Trubice 2 má pravděpodobně celkem 3 otvory. Od definitivního konce a prvním otvorem je vzdálenost $22 \mathrm{~mm}$, mezi otvorem 1 a 2 je $26 \mathrm{~mm}$ a mezi 2 a 3 je $24 \mathrm{~mm}$. Tato dvojitá trubice má ovšem otvorů více, ale v rámci zvukového experimentu operujeme se čtyřmi tóny tak, jako je tomu u dalších experimentů.

I když má experiment 1 chybný počet otvorů, což může být považováno jako hrubý omyl, celkovou tonalitu nástroje neovlivní. Tu ovlivňuje vnitřní vývrt,

\footnotetext{
${ }^{7}$ Údaj byl získán na základě relevantního zdroje opírajícího se o informace Bo Lawergrena, který artefakty měl k dispozici a 17 fragmentů poskládal do původních pěti. Je to výchozí bod, ze kterého vycházela i rekonstrukce B. Browna.

${ }^{8}$ Experiment - dvě příčné flétny o různých tloušťkách stěn a intonace tónů se nelišila.
} 


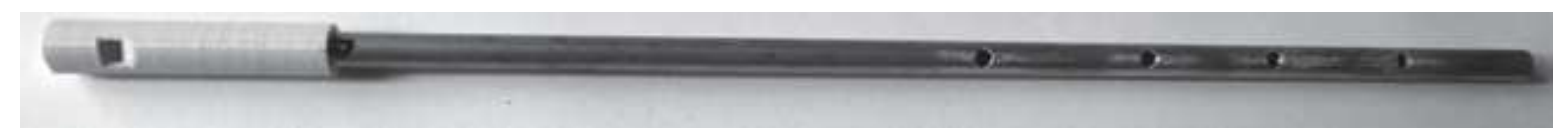

Zdroj: autorka

vzdálenost otvorů ke hraní a jejich průměr daný ostatními parametry. V tomto směru $\mathrm{k}$ pochybení nedošlo. Více otvorů jen ukazuje na sedmitónovou řadu čili celotónovou stupnici, v mezopotámském tónálním systému označovanou jako modus (Dumbrill 2013). O píštalách se sedmi tóny se dokonce zmiňuje i klínopisná tabulka, VAT 12617, kterou dnes nalezneme v Staatliche Museen zu Berlin. Nacházíme tam sumerský záznam IMIN-E TI-GI a jeho překlad „sedm tónü“ (CDLI n. d.).

Pokud se zaměříme na témbr ${ }^{9}$ nástroje, získáme zvukový potenciál podobný rekonstrukci B. Browna, ačkoliv počet otvorů se liší. Tady ovšem přicházíme s variantou nástroje typu "argul". Barva zvukově odpovídá současnému arabskému nástroji výše uvedeného. Sestupnou tónovou řadu naší rekonstrukce představují tóny: Ais-G-Fis-E-Dis. Řada obsahuje některé tóny z mezopotámského tonálního systému typu „embūbu“ (Dumbrill 2005: 54).

\subsection{EXPERIMENT 2 (VIZ OBRÁZEK 9)}

Experiment 2 byl proveden $\mathrm{s}$ J. Ondříčkem, jemuž lze připsat autorství 3D tisku labia a technickému výkresu 3D plánu. V rámci pokusu jsme pracovali opět $\mathrm{s}$ připravenými trubičkami s požadovaným průměrem, do kterých se vyvrtaly otvory podle stanovených rozměrů. Trubičky, se kterými jsme experimentovali, byly mosazné. Na jednu z trubic se vyvrtaly čtyři otvory, na druhou tři. Místo plátku jsme zde pracovali s labiem, aby vznikla píštala typu „whistle“, která však přináší zcela jiný zvukový záznam. Alternativa 3D tisku je pouze provizorní, protože zvukový efekt nemá potřebnou rezonanční kvalitu. Materiál tu hraje roli z hlediska akustiky.

Experiment 2 přinesl dechový nástroj, jehož zvuk, kvůli již zmíněným příčinám, nemá vysokou zvukovou kvalitu, protože z něj slyšíme intonační nepřesnosti. Výsledná tónová řada s těmito tóny, které jsou seřazeny od nejvyššího k nejnižšímu, je: Cis-Ais-Gis-F-Dis (Dumbrill 2005: 54), navzdory odlišné frekvenci, ve které se modus pohybuje, obsahuje také tóny tzv. „embūbu“ (Dumbrill 2005: 54). Jedná se o část modu, který v rámci mezopotámského tonálního systému je označen „em-bu-bu in ša em-bū-bi". Tónová řada se opírá o klínopisnou tabulku UET VII 74 podle překladu, který zhotovil O. R. Gurney (Dumbrill 2005: 54). Odlišnost je pouze $\mathrm{v}$ tónu F, podle tabulky by měl spíše znít jako Fis. Tato odchylka je sice malá, ale tóny zní zastřeně, a tak se dají velice obtížně determinovat. Při opakovaném hraní bývá intonace dosti kolísavá.

Jako sekundární efekt pokus přinesl další výsledek. Tóny se pohybují ve vysokých frekvencích odpovídající přibližně ptačímu zvuku, což bylo zjištěno

\footnotetext{
${ }^{9}$ Témbr $=$ barva zvuku.
} 
během zvukové zkoušky popisované píštaly, v jejíž blízkosti se nacházel papoušek senegalský, latinsky „poicephalus senegalus“. Tato zkušenost neměla být původně do experimentu zahrnuta, ale opeřenec během hry na tento druh píštaly velmi intenzivně reagoval, a na základě této reakce zde přišlo na mysl porovnat ptačí zpěv se zvukem rekonstruovaného nástroje. Experiment s druhou trubičkou přinesl následující tónovou řadu se čtyřmi tóny Ais-G-F-Dis, což odpovídá třem otvorům. Výsledkem jsou dvě tónové řady, kde tón $\mathrm{G}$ se liší o půltón. Tento výsledek znamená, že pokud by druhá z trubic měla být jako doprovodná, vytvářela by některé souzvuky s druhou, disonantní, neladící dvojzvuky, které se podle některých klínopisných hudebních tabulek nazývají „nečisté tóny“. Kvalita každé stupnice v tomto paradigmatu je determinována pozicí tritónu v rozmezí enneachordu. „Starobabylonský tonální systém je založen na diatonickém sestupném uspořádání, $v$ němž je sedm různých tónin současně s osmou, která je výsledkem metody založené na transpozici první z těchto tónin vyšši o půltón" (Dumbrill 2007a: 16).

Problém tzv. tritónu neboli cosi „nedobře znějici“ “ řšili ve staré Mezopotámii palindromickým řazením tónů tak, že se doladily struny bud jejich dotažením, nebo povolením do patřičného tónového modu. Podle R. J. Dumbrilla je tento systém označován jako enneatonický. Citujme z tabulky UET VII 74 (U.7/80): „Je-li harfa laděna $v$ modu embūbum, $v$ rozsahu od struny 6 ke struně 3, pak kitmum zní ne zcela čistě, protože je struna 3 podladěná, v tom př́padě harfa bude naladěná do modu pítum" (Dumbrill 2007b: 18). Tento modus má rozmezí strun 3 až 7.

Flétny poté, co se do nich vyvrtají otvory, mají jasně dané tónové řady, jejichž ladění se již nedá ovlivnit. Ladicí postupy strunných nástrojů, které jsme zde popsali, mají poukázat na to, jaký do̊raz se ve staré Mezopotámii kladl na čistotu tónu. Jako citaci jsme uvedli právě modus „embūbu“, protože stejně se také překládá i typ aerofonu, jehož rekonstrukci zde právě uvádíme. Tento modus mající některé výškové frekvence odpovídající zmíněné mezopotámské tónině, je pouze přibližný, hrané tóny na píštale s labiem jsou velmi nízké kvality, ne vždy tento sled tónů zazní intonačně přesně. Nesoulad s tónem g a gis obou trubic může být dán i konstrukční nepřesností.

V akkadských zápisech nalézáme pojem „embūbu“ nebo také „enbūbu“, „ebbūbu“, který je chápán jako „flétna“, dále ve spojení embūb hašê má význam jako dechová píštala či trubice (Gelb et al.: 137). Záznam pochází z období starobabylonského. Se spojením „embūbu in ša embūbi" tu máme sousloví „hráč na flétnu“.

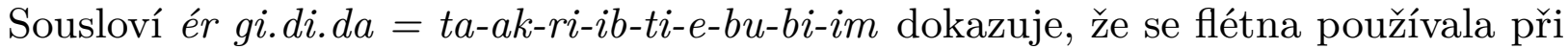
smutečních událostech, nebot vyjadřuje „nářek za doprovodu flétny“ (Gelb et al.: 138). Synonymum k výše uvedenému názvu je malñlu, či malīliš nebo maln̄lu in ša malīli, který překládáme jako „rákosová flétna". Se smutečním obřadem souvisí i vyjádření „ina irtišu ša kīma ma-li-li qú-bi-i ihallalu“, což znamená „v jeho hrudi, jež zní jako flétna sloužící k truchlení" (Civil et al.: 164). Tento pojem nejen že nám prozrazuje název hudebního nástroje, ale i materiál, ze kterého flétna byla vyrobena. Některé zdroje ji popisují jako tenkou foukací trubičku nebo píštalu s malým vnitřním vrtem (Ertelt, von Loesch, Zaminer 2006: 10). 


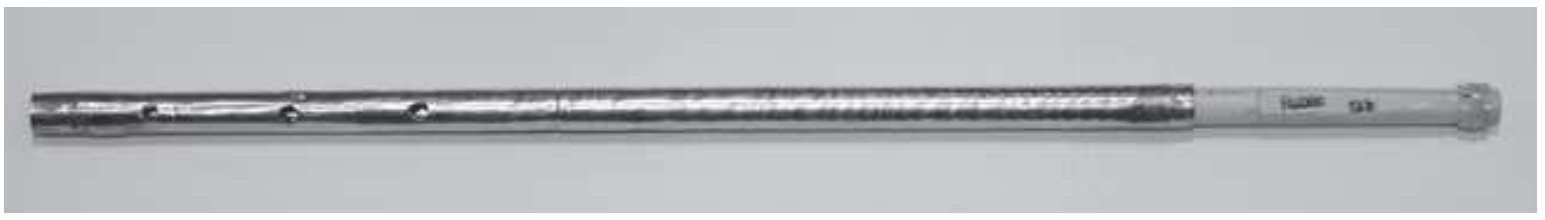

Zdroj: autorka

Obrázek 11: Výrobní proces 1 - rolování

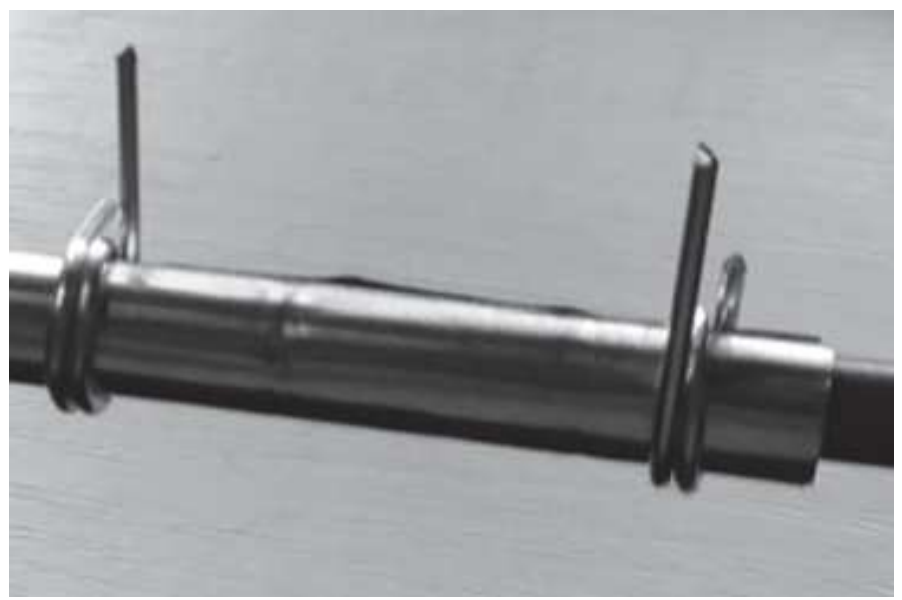

Zdroj: autorka

\subsection{EXPeriment 3 (VIZ OBRÁZeK 10)}

Experimenty, o nichž jsme až doposud mluvili, vycházely již ze zhotovených trubiček. Následující pracovní postup je zde rozšiřren a obohacen o výrobu trubiček samých z připraveného plechu, jehož mikrostruktura přibližně odpovídá mikrostruktuře rekonstruovaného artefaktu. Tento povrch byl připraven pomocí kamenného kladívka, prostřednictvím kterého se v nejstarších obdobích mezopotámských dějin tepaly plechy o různých tlouštkách. Protože píštala nalezená v Uru měla podobu pravidelné tenké trubice, která se ani nerož̌šřovala ani nezužovala, její výroba probíhala pravděpodobně takto: ze stříbra se vyrobil plech o určité tlouštce prostřednictvím malé kamenné paličky. Zde bylo nutné docílit náležitě kvalitního povrchu, a tak jako deska sloužil hladký plochý kámen, pravděpodobně hematit (Olson 2010: 234, 236). Archeologie prokázala, že tlouštka některých kovových plechů mnohdy dosahovala až 0,25 mm (Moorey 1999: 226). Trubice popisovaného artefaktu se vyrobila rolováním (viz Obrázek 11) plechu a za tepla se konce spojily (viz Obrázek 12).

Po vyrobené trubici přichází fáze umístit otvory do nástroje a stanovit směr hraní. Tady se opíráme o návrh B. Lawergrena, který otvory umístil od konců, protože to je v souladu s konstrukcí a laděním aerofonů (Kašpařík 2016). Vzdálenosti mezi nimi jsou dány parametry artefaktu. Otvory nám vycházejí zhruba do poloviny délky trubice a od plátku neboli jazýčku se nachází v jejich druhé polovině. Tento důležitý údaj také koresponduje s ikonografiemi. 
Obrázek 12: Výrobní proces 2 - tepelná úprava - spojené konce (popis obrázků vždy pod fotografii)

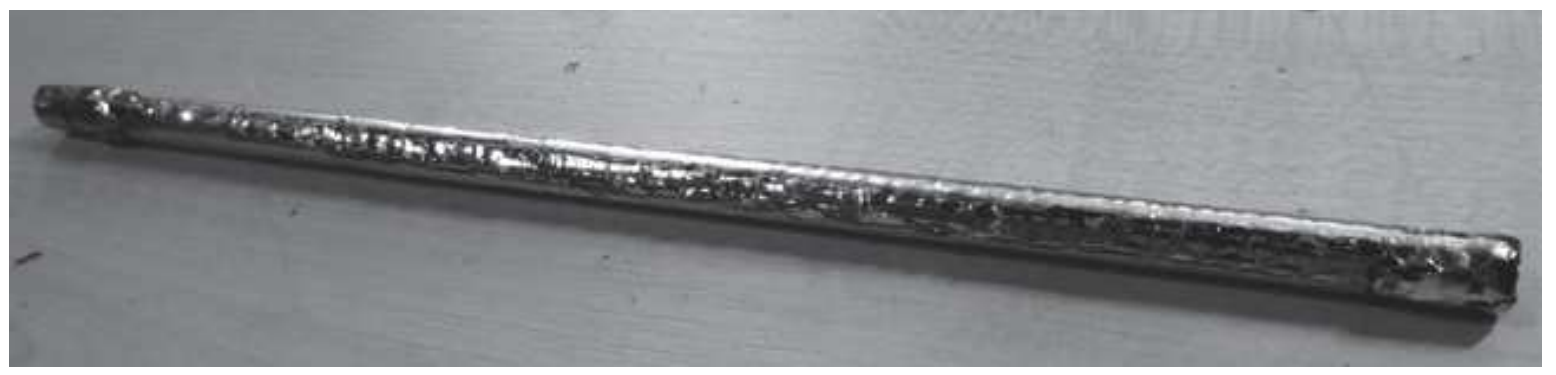

Zdroj: autorka

Konečně se dostáváme k tónovým řadám rekonstruovaných trubic. V tomto experimentu jsme použili plátek vyrobený z rákosu. Vzhledem k vysoké obtížnosti tuto část nástroje vyrobit, bylo nutné využít profesionální výrobce plátků. Délka je stanovena na základě experimentu, protože tolik důležitou součást nikdo dosud nenalezl. Plátky mohou mít různou délku, a z tohoto důvodu je zcela irelevantní jeho parametr uvádět, protože tu neoperujeme s konstantou, ale s variabilní proměnnou. I průměr se nepatrně může měnit v rozmezí od 5 do $7 \mathrm{~mm}$. Tóny, které z této rekonstrukce vznikly, jsou sice opět pouze orientační, přesto tu máme zvuk s vyšší kvalitou. Vyšla následující tónová řada: trubice se třemi otvory zní takto: Dis-Cis-H-Ais. Tón ais je někdy intonačně méně přesný. Trubice, která má otvory čtyři: F-E-Dis-D-Cis. Podle zásad mezopotámského tonálního systému jsou i v tomto případě tóny řazeny sestupně stejně jako ve všech experimentech.

\section{VÝZNAM A VÝSLEDKY EXPERIMENTŮ V KONTEXTU S HMOTNÝMI I PÍSEMNÝMI PRAMENY}

Všechny uvedené experimenty měly nabídnout různé varianty zvuků na základě nalezených aerofonů v Uru. Výsledkem však není definitivní imitace objevených píštal, ale hra se zvuky, které se mohou za různých okolností měnit.

Obecně se dá říci, že přesnou rekonstrukci omezovala skutečnost, že se zde pracovalo pouze se sekundárními zdroji, byt jimi byly kvalitní fotografie. Dalším faktorem, který byl již uveden, ale přesto je vhodné jej znovu připomenout, je, že artefakty byly $\mathrm{v}$ průběhu let velmi poškozeny, a přístup $\mathrm{k}$ nim není tedy možný. Z toho plyne i fragmentární podoba artefaktu, který se dokonce rozlomil na fragmenty menší, než je opět v původních pět znovu seskládal v roce 2000 B. Lawergren.

A tou zásadní překážkou je chybějící složka nástroje, díky níž se dá vyvodit tónová řada, která se označuje jako plátek či jazýček. Dokonce není k dispozici ani dostatek relevantních sekundárních zdrojů, protože kvalitní analýzou stř́ibrných aerofonů se zabývalo jen minimum odborníků, jimiž byl B. Lawergren a B. Brown, většina o nálezech hovoří v kontextu nálezů z pohřebiště v Uru.

Zdroje se však nezabývají myšlenkou, zda by chybějícím komponentem nemohlo být i labium, díky kterému bude znít kovová píštala zcela odlišně, nežli rezonátor tvořený jazýčkem $\mathrm{z}$ rákosu. Proto $\mathrm{v}$ této studii přicházíme $\mathrm{s}$ experimentem, 
kde jazýček nahrazuje labium. Tuto možnost dosud nikdo ve svých analýzách nezohledňoval.

V rámci jednotlivých experimentů se pracovalo nejen s vytvořenými trubičkami, ale i s trubicemi, které byly vyrobeny podobnou technologií, jaká se používala ve staré Mezopotámii. Všechny experimenty jednoznačně potvrdily, že tónovou řadu ovlivňuje jazýček. Experiment 1 a 3 vytváří podobnou zvukovou kvalitu díky jazýčku vyrobeného ze stejného materiálu, čímž je rákos. Podobná zvuková kvalita představuje nikoli ekvivalentní tónovou řadu, ale vykazuje shody v barvě zvuku. Všechny realizované píštaly produkují takové tóny, které jsou součástí modu tzv. „embūbu“, ačkoliv tóny z experimentu 2 se nacházejí ve vysokých frekvencích. Vytvořené tónové řady korespondují s mezopotámským tonálním systémem, přesto jsou vinou konstrukční nedokonalosti někdy intonačně nepřesné a bylo je velmi obtížné porovnat s klavírem, díky němuž se mohly tóny pojmenovat, čemuž napomohly i nahrávky pořízené píštalami vzešlé z této rekonstrukce. Je logické, že tóny odpovídají stejnému modu, protože u všech rekonstruovaných trubic byl zachován vnitřní vrt s mírnými odchylkami a délka. Vygenerované tóny konkrétního modu potvrzuje správný pracovní postup s dodrženými parametry.

Možná čtenáře napadne otázka, proč byly tyto experimenty prováděny, když už rekonstrukci provedl B. Brown. Pokud porovnáme jeho přístup s naším, zjistíme některé odlišnosti. Jednou z nich je metodologický přístup. B. Brown vychází z podrobných studií artefaktů z období relativně mladších, než ze kterého pochází aerofon z Uru. Proto se domnívá, že se jedná o nástroj typu „aulos“. Nástroj tohoto druhu má dlouhou tradici v mladších obdobích dějin Blízkého východu a dále pak především v antickém Řecku, což bohatě potvrzuje ikonografie. Z ní můžeme odvodit, že místo původu nástroje typu „aulos“ se nachází ve Středomoří a odtud se dále šírí i na Blízký východ. Kdy však dochází k přesunu tohoto aerofonu ze Středomoří na Blízký východ, je ovšem problematické dohledat. Tradice zdvojených píštal v blízkovýchodním regionu na základě ikonografických a písemných zpráv se zdá být přijata okolo 21. st. př. n. 1., ale tato datace je pouze orientační.

Přicházíme s metodologií, která pracuje s analýzou aerofonů, které se vyskytovaly v období 2700 až 2300 př. n. l. v různých oblastech Blízkého východu, například v Egyptě, kde jsou právě jednoduché flétny již od nejstarších období relativně hojně zastoupeny, a naopak v období mladších jsou na reliéfech nahrazeny jinými nástroji, a pokud zde flétny najdeme, pak v jejich zdvojené podobě. Což vede k zamyšlení nad možností, že by píštaly z Uru, které se zde našly, byly sice po dvou, ale na každou z nich mohl hrát instrumentalista samostatně.

Výsledek výzkumu přichází jen s další možnou verzí, nikoli s definitivním stanoviskem o tom, že se tu našly dva samostatné dechy, protože ikonografie, která by hypotézu potvrdila, je nedostatečná. I když pro tuto domněnku hovoří i některé písemné prameny v rámci mezopotámské literární tradice, kde čteme v několika příbězích zmínky o rákosové píštale, není těchto záznamů př́liš mnoho. Uvedeme si ještě jednou citaci o rozlomené píštale, která byla pouze jedna. Pokud by byly dvě, naříkala by Inanna, manželka Dumuziho nad dvěma rozlomenými píśtalkami: „Oni rozlomili rákosovou píštalu, na kterou pastýř hrával“ (Wolkstein, Kramer 1983: 71). 


\section{ZÁVĚR}

Na závěr lze shrnout, že se tu nabízí více variant rekonstrukcí a každá z nich má své opodstatnění. Na základě výzkumu písemných a hmotných pramenů se pak lze $\mathrm{k}$ některé $\mathrm{z}$ nich více přiklonit a jinou spíše vyloučit. Barva zvuku se tu shoduje s experimentem 1 a 3 . Přesto je vhodné přinést další data o těchto artefaktech, protože z našeho výzkumu vyvstaly další nezodpovězené otázky kvůli již zmíněným důvodům.

Zvuky, které vznikly při této rekonstrukci, mohou připomínat při troše fantazie zvuky živočichů, což samozřejmě neodpovídá standardům evropské klasické hudby, ale v období ranědynastickém mohly být nositeli určitých symbolů.

Experiment 2 připomíná ptačí hvizd, experimenty 1 a 3 zvuk jelena či býka. Ačkoliv o tónové řadě mohou být vedeny dlouhé diskuse, barvy zvuku už tak rozmanité nejsou, poněvadž se tu nabízí podobnost se zvuky určitých živočichů. Tím, že se ranědynastické období vyznačuje zoomorfními rysy, tuto domněnku nemusíme zcela zavrhovat.

Význam ptactva je často spojován s dušemi zemřelých a tento motiv vidíme v mnoha kulturách, a tudíž i v kultuře mezopotámské (Patai 1983: 130). Pokud přihlédneme ke strunným nástrojům ze stejného pohřebiště, případně i k jiným artefaktům, setkáme se tu s živočichy, jimiž byl např́íklad jelen nebo tur. Co všechno tito tvorové ve starověké Mezopotámii symbolizovali, o tom se jen můžeme dohadovat, ale četnost nálezů z ranědynastického období dokazuje jejich mimořádný význam. Podle interpretace M. Marcetteau jelen zdobí stříbrnou lyru (U.1235) a vyskytuje se i jako samostatná figura, která je vyrobená z mědi (U.12356). Tento živočich také patří do myticko-kosmologického páru s býkem. Díky vystupujícím parohům i on se symbolicky přirovnává k hudebnímu nástroji. Parohy se přirovnávají k větvím stromů, které se každým rokem rozrůstají. Představují tudíž symbol znovuobnovení životního cyklu. Je spojen s časem, stejně tak jako hudba probíhá v čase. Býk, kráva, tele a jelen jsou živočichové, kteří jsou součástí jedné skupiny. Propojují hudbu a čas a ztělesňují tak metaforu hudebního cyklu skrze určité vývojové fáze - zrození (býk), růst (kráva a tele) a konec života (jelen) (Marcetteau 2009: 69).

\section{BIBLIOGRAFIE}

Ancient History Encyclopedia. 2012. „Aulos.“ [online] Ancient History Encyclopedia [cit. 18. 10. 2017]. Dostupné z: https://www.ancient.eu/Aulos/.

Braun, J. 2002. Music in Ancient Israel/Palestine. Cambride: Company Grand Rapids.

Brown, B. 2002. The Silver Pipes of Ur: Material Evidence for the Pitch, Intonation and Texture of Sumerian Court Music, 2450 BC. Glasgow: Royal Scottish Academy of Music \& Drama.

CDLI. n. d. „VAT 12671.“ [online] Cuneiform Digital Library Initiative [cit. 18. 10. 2017]. Dostupné z: http://cdli.ucla.edu/?q=cdli-tablet.

Civil, M., J. Gelb, A. L. Oppenheim, E. Reiner. 2004. The Assyrian Dictionary, volume 10, Part 1/M. Chicago: The Oriental Institute Chicago. 
Collon, D. 2008. „Playing in Concert in the Ancient Near East. “ Pp 47-66 in ICONEA 2008. Proceedings of the International Conference of Near-Eastern Archaeomusicology held at Senate House, December 4-6 2008, Institute of Musical Research and University of London, England. London: The British Museum.

Dumbrill, R. J. 2007a. „Modus Vivendi.“ Pp 1-42 in ICONEA 200\%. Proceedings of the International Conference of Near-Eastern Archaeomusicology held at Senate House, Institute of Musical Research and University of London, England. London: The British Museum.

Dumbrill, R. J. 2007b. „Review of Archaeomusicology in the Ancient Near East." Pp 1-20 in ICONEA 200\%. Proceedings of the International Conference of Near-Eastern Archaeomusicology held at Senate House, Institute of Musical Research and University of London, England. London: The British Museum.

Dumbrill, R. J. 2013. The Course of Archaeomusicology from the under the Direction of Professor of Archaeomusicology. London, 17.-27. 9. 2013.

Dumbrill, R., J. 2005. The Archaeomusicology of the Ancient Near East. London: Trafford.

Ertelt, T., H. von Loesch, F. Zaminer. 2006. Geschichte der Musiktheorie 2. Mythos zur Fachdisziplin: Antike und Byzanz. Darmstadt: Wissenschaftliche Buchgesellschaft.

Flutopedia. 2018. "Cycladic Statue and Double-Flute player." [online] Flutopedia. En Encyclopedia for the native American flute [cit. 16. 11. 2017]. Dostupné z: http://www. flutopedia.com/img_cycladic.htm.

Gelb, J., T. Jacobsen, B. Landsberger, A. L. Oppenheim. 2004. The Assyrian Dictionary volume 10, Part 4/E. Chicago: The Oriental Institute of The University of Chicago. Hoskovec, L. 2008. „Arundo donax L. tresṫ obecná.“ [online] Herbár [cit. 15. 10. 2017]. Dostupné z: http://botany.cz/cs/arundo-donax/.

Chondrogianni-Metoki, A. 2015. "The neolithic settlement of 'Toumba Kremastis Koiladas' (Part 3). " [online] Archeology \& Arts [cit. 14. 10. 2017]. Dostupné z: http://www. archaeology.wiki/blog/2015/11/16/neolithic-settlement-toumba-kremastis-koiladaspart-3/.

Kašpařík, J. 2016. Rekonstrukce dřevěných dechových nástrojů. Empirický výzkum 2015/2016 - Blažejovice - Brno.

Koç University. 2017. „Relief depicting a banquet scene with musicians (North gate), East wall at Karatepe." [online] Koç University. Suna Kiraç Library [cit. 16. 10. 2017]. Dostupné z: http://digitalcollections.library.ku.edu.tr/cdm/ref/collection/GHC/id/17195.

Kroll, O., A. Baines, H. Morris, D. Riehm. 1968. The Clarinet. New York: Taplinger.

Lawergren, B. 2000. „Extant Silver Pipes from Ur, 2450 BC.“ Pp 121-132 in E. Hickmann. Studien zur Musikärchologie. Nordrhein-Westfalen: Orient.

Marcetteau, M. 2009. „The horn quartet: a study of bull, cow, calf and stag figures on Sumerian lyres. " Pp 67-72 in R. J. Dumbrill, M. Marcetteau (eds). Arane 1: Archaeomusicological Review of the Ancient Near East. London: ICONEA.

Metropolitan Museum of Art. n. d. „Inlay: woman wearing a cylinder seal, playing a flute." [online] Metropolitan Museum of Art [cit. 16. 11. 2017]. Dostupné z: https: //www.metmuseum.org/art/collection/search/325451.

Montagu, J. 2007. Origin and Development of Musical Instruments. Lanham: Scarecrow Press INC.

Moorey, R. 1999. Ancient Mesopotamian Materials and Industries: The Archaeological Evidence. Winona Lake: Eisenbrauns.

Oling, B., H. Walisch. 2004. Encyklopedie hudebních nástrojů. Praha: Rebo. 
Olson, G. R. 2010. Technology and Science in Ancient Civilisations. Oxford: ABC-CLIO, LLC.

Otto, J. 1992. Ottưv slovník naučný: Ilustrovaná encyklopedie obecných vědomostí. Praha: J. Otto.

Patai, R. 1983. Field of Offerings: Studies in Honor of Raphael Patai. Ontario: Herzel Press Publication.

Penn Museum. n. d. „Silver Pipes from Ur.“ [online] Penn Museum [cit. 15. 10. 2017]. Dostupné z: https://www.penn.museum/collections/object_images.php?irn=224933.

Pishikova, E. 2014. Tombs of the South Asasif Necropolis, Thebes, Karakhamun (TT223) and Karabasken (TT391) in the Twenty fifth Dynasty. New York: American University in Cairo.

Sachs, K. 2006. The history of musical instruments. New York: Dover.

Shaw, I. 2003. Dějiny starověkého Egypta. Praha: BB art.

Scheel, B. 1989. Egyptian Metalworking and Tools. Aylesbury: Shire Publication LTD.

Špelina, M. 2017. Osobní sdělení, Plzeň, 25. 9. 2017.

The British Museum. 2017. „Tomb-painting EA37981.“ [online] The British Museum [cit. 4. 11. 2017]. Dostupné z: http://britishmuseum.org/research/collection_online/collection _object_details/collection_image_gallery.aspx?partid=1\&assetid=244310001\&objectid $=112658$.

Traveltoeat. 2014. „Qeen Pu-abi of Ur." [online] Traveltoeat.com [cit. 31. 5. 2018]. Dostupné z: https://traveltoeat.com/wp-content/uploads/2014/02/wpid-Photo-Jun-202013-722-AM4.jpg.

Verner, M., L. Bareš, B. Vachala. 2007. Encyklopedie starověkého Egypta. Praha: Libry. Virgilio. n. d. „The Hierakonpolis Palette.“ [online] Virgilio.it [cit. 16. 11. 2017]. Dostupné z: http://xoomer.virgilio.it/francescoraf/hesyra/palettes/dogs.htm.

Vyšata, J. 2017. Osobní sdělení. Plzeň, 5. 9. 2017.

Wolkstein, D., N. S. Kramer. 1983. Inanna Queen of Heaven and Earth: Her Stories and Hymns from Sumer. New York: Harper \& Row.

\section{SUMMARY}

The discovered fragments clearly show that we are dealing with two pipes without the presence of a reed. As the most important component was not preserved, it was not possible to determine whether this is a reed instrument or flue pipe. This component is crucial to determine the tonal mode, and thus we experimented with both a reed and mouthpiece. Because we did not have the proper material at hand to create the mouthpiece, we used a $3 D$ printer, although this was only a provisional alternative. According to the majority of experts, the reed was created from the plant of the same name, which is a material that could not have been preserved, similarly to the woody plant suitable for making a mouthpiece. Due to the great difficulty of making a reed, we had this component created by reputable experts according to the diameter of the pipe. Despite this effort, it was not possible to create a reed independently, even after several tries. The material either snapped or produced no sound.

The overall sound potential shows an interesting color, but the reconstructed tone rows are only hypothetical. These modes are located in diverse pitch frequencies depending on whether a reed or mouthpiece was used. Playing with a mouthpiece generated tones that some cuneiform scripts point to as "embūbu" mode (Dumbrill 2005: 54). They are ordered from highest to lowest: $c \sharp-a \sharp-g \sharp-f-d \sharp$ with a pipe with four holes. With a flute with three openings, we receive the following tones - $a \sharp-g-f-d \sharp$. Reconstruction of the pipes with 
reeds and metal plates produced in advance yielded these tones: (with three openings) $d \sharp-$ $c \sharp-b-a \sharp$. The tone $a \sharp$ is sometimes less accurate in terms of intonation. The pipe that has four tones produces the tones: $f-e-d \sharp-d-c \sharp$. In the case of a doubled pipe (arghul), we received the following tones: $a \sharp-g-f \sharp-e-d \sharp$. The sound of the flute with a mouthpiece is highly reminiscent of a bird's whistle, which could be seen in the reactions of a parrot while playing this aerophone. Experiments with reeds of varying length show a match in the color of the sound from which this sound potential is created.

Due to the absence of the reed or mouthpiece, the tone rows can be very diverse, but not the colour of the audial effect. If we use a reed while playing, we generate a sound that is reminiscent of an animal - in this case perhaps a deer, bull, or other animal. The Early Dynastic Period is characterized by zoomorphic traits and therefore the resulting sound quality of the reconstructed aerophones supports this context.

The realization of the two aerophones provides a new interpretation of the silver flutes of Ur. However, this new viewpoint cannot repudiate the hitherto acknowledged hypothetical reconstruction by B. Brown, as we have only several iconographic findings from the time when these wind instruments were created. Despite this fact, they contradict the method of playing suggested by B. Brown. Instrumentalists in this case do not play on a doubled type of flute. Based on this study, the tradition of this method of playing came to the Middle East likely in the $21^{\text {st }}$ century BC. There is only one artifact available of an instrumentalist playing on an "aulos" type instrument. This instrument, however, originates in the Cyclades Islands, from which it is difficult to prove mutual contact with Mesopotamia. Even if this was proven, this individual finding does not have the sufficient historical value to prove that playing on doubled aerophones already existed in the Early Dynastic Period.

This article offers methodology that works with the analysis of simple and doubled aerophones. Many findings of straight musical instruments were deposited in pairs; this however, does not prove that the instruments were played simultaneously as in the finding of the aerophones or Ur. Although it is found only in a limited amount, the iconographic depiction from the same time period and area seem to disprove the option of an "aulos" type instrument. 